\title{
Formation conditions of hydrothermal Monazite of Jolotca ore field, Ditrău Alkaline Massif
}

KRISZTIAN FINTOR ${ }^{1}$, HELENA WALTER ${ }^{1}$ AND ELEMER $^{-}$ PAL-MOLNAR $^{2}$

${ }^{1}$ University of Szeged

${ }^{2}$ University of Szeged, Hungary

Presenting Author: efkrisz@gmail.com

Our advanced technology tools are now unimaginable without the use of rare earth elements (REE), so research into the natural enrichment and formation conditions of REE ores is one of the greatest challenges of geology. The Jolotca ore field of the Ditrău Alkaline Massif (DAM) is the most important potential deposit of REE ores in the Carpathian Basin, and one of the most important REE deposit of Europe [1]. The DAM is a Mesozoic igneous complex located in Transylvania, Romania, in the Eastern Carpathians. The Jolotca ore field is located at the NW part of the DAM and contains mineralized veins that are dominated by monazite, where the ore mineralization exhibits complex characteristics from late magmatic to hydrothermal processes [2]. The vast majority of hydrothermal originated Monazite form aggregates of radially arranged columnar crystals. Xenotime occurs much less frequently, and can be observed as disseminated anhedral and subhedral crystals. Contact of Monazite and Xenotime is sharp without any reaction front. Chemical composition of Monazite $\left(\mathrm{UO}_{2}<0.1 \mathrm{wt} \%\right.$; $\mathrm{ThO}_{2}: \sim 1-5$ $\mathrm{wt} \%)$ and Xenotime $\left(\mathrm{Eu}_{\mathrm{N}}: \sim 2-12 \mathrm{wt} \% ; \mathrm{Gd}_{\mathrm{N}}: \sim 12-24 \mathrm{wt} \%\right)$ supports the hydrothermal origin of both phases. Characteristics of these phases give a possibility to estimate the formation temperature of Monazite by using its $\mathrm{Y}$ content in a Monazite/Xenotime multicomponent system [3]. By using this procedure $332 \pm 18{ }^{\circ} \mathrm{C}$ to $408 \pm 18{ }^{\circ} \mathrm{C}$ range is obtained to formation conditions of Monazite in a broad (0.1-700 MPa) ambient pressure domain. The data reported here fit well into the currently known mineral formation sequence of the Jolotca vein mineralization [2].

This research was supported by the National Research Development and Innovation Office - NKFIH, 135089.

References:

[1] Goodenough, Schilling, Jonsson, Kalvig, Charles, Tuduri, Deady, Sadeghi, Schiellerup, Müller, Bertrand, Arvanitidis, Eliopoulos, Shaw, Thrane \& Keulen (2016) Ore. Geol. Rev. 72/1, 838-856.

[2] Hirtopanu, Fairhurst, Jakab \& Udubasa (2017) Rom. J. Mineral Deposits, 90/1-2, 27-40.

[3] Mogilevsky (2007) Phys. Chem. Minerals 34, 201-214. 